\title{
Students' Listening Difficulties in English as a Foreign Language Learning at Secondary School in Indonesian Context
}

\author{
Syifa Nadhira ${ }^{1, a)}$, Silih Warni ${ }^{2}$ \\ Universitas Muhammadiyah Prof. DR. HAMKA \\ a) syifanadhira14@gmail.com
}

\begin{abstract}
This study aims to investigate the students' difficulties in listening and to explore the factors of students' listening difficulties. The writer uses mixed methods (qualitative and quantitative) with questionnaire and interview as the data collecting techniques. The participants of this research are 100 students of a senior high school in West Java who filled in the questionnaires and 8 students who took part in in-depth interviews. The quantitative approach is used to show the numeric data of the questionnaire about students' listening difficulties and the qualitative approach is applied to explore the factors of students' listening difficulties. The findings of the research show that the difficulties in listening skills faced by students include unfamiliar words, rate of speech, unfamiliar accent, unclear pronunciation, recording quality, and inadequate facility. As for the factors of those difficulties, it involed the students' background knowledge, lack of practices and environment noise.
\end{abstract}

Keywords: Listening Comprehension, Listening Difficulties, Perceptions.

\section{INTRODUCTION}

Listening skill is one of the most important skills that learners need to master in learning English [1]. However, teachers have not been much concerned with this area of skills in some school contexts. Gilakjani and Sabouri [2] found many teachers only focus on writing, reading and mastering vocabulary so that learners often face difficulties while learning listening skills. The difficulties faced by students could be due to cultural differences and unfamiliar words [2]. In a study conducted by Hamouda [3] in the university context in Saudi Arabia, a lot of students in the English Department have severe problems in listening comprehension. He found that students show an inadequate capability in listening course. They couldn't comprehend what native speaker said, spoken material of the course, and didn't pay full attention to the activities. These indicate that researchers have put a big concern on the listening skills in English as a foreign language learning context.

Listening is a process of hearing the sound of the speaker and finding the meaning by the listener [2]. According to Rost [4], while listening, the listener receives the speaker saying and catch the idea. In addition, While $\mathrm{Gu}$ [5] defined listening as a listening comprehension with meaning of an active process of receiving the incoming data and creating meaning in another way. In other words, listening could be understood as an interaction between the speaker and the listener to convey and comprehend messages or information.

There are four types of listening which include appreciative, comprehensive, critical/deliberative, and empathetic listening [6]. Appreciative listening means the listener listens to something from the speaker to get the pleasure, not a dangerous thing. For example, come to the music concert. Comprehensive listening means the listener listens to the speaker to get information or the 
message of what they are saying. For example, watching a news on television. Deliberative listening means the listener analysed the speaker saying critically to decide whether it makes sense or not. The last is empathetic listening, it means the listener involves their emotion while listening to the speaker. In comprehending the idea from the speaker, the listener must go through six stages of listening: hearing, understanding, remembering, interpreting, evaluating, and responding some stages [6]. The first stage is hearing when the listener will hear the sound of the speaker. After hearing the sound, the listener will try to catch and process the meaning of the message from the speaker saying. This stage is known as understanding. The things that heard by the listener from the speaker will be remembered and this stage is remembering. The next stage is interpreting in which the listener will consider the message of the speaker and response the speaker. The last stage is evaluating where listener think critically to judge or evaluate the message of the speaker saying.

Students might have some problems in listening comprehension. The problems which commonly appear are unfamiliar accent, unclearly pronunciation, unfamiliar words, rate of speech, and grammatical structure [7]. Yagang [8] classified the listening problems into four sources comprising the content, the speaker, the listener, and the setting. His findings are approximately similar to Lotfi [9] which classified the sources into six major categories including process, input, listener, task, affect, and context. The process factor shows the perception of the students about listening problems in the listening comprehension process with different aspects. Process means the way how learners use different things in interpreting what the speaker is saying. The second factor of aural input is defined as a discourse of the second language in listening. The third factor dealing with listener shows the perception of the students on listeners' characteristics. The fourth factor shows the perception of the students on their task with the characteristics that are described as the varied purpose in listening and its responses. The fifth factor of affect is the affective responses in listening comprehension. The last factor is context which is defined as the learning context in listening comprehension.

A number of study concerning the difficulties of listening faced by students in English as a foreign language learning context have been condeucted. Several studies particularly investigated the factors of listening difficulties using qualitative approach with different methods of collecting data. With interviews, Maulida [10] revealed some problems encountering students in listening which include lack of vocabulary, poor grammar knowledge, length of spoken text, unfamiliar topic, failure to concentrate, anxiety, lack of interest, various accents, pronunciation, poor quality tape or disks, and inability to apply listening strategy and concentrate.
Another study was conducted by Darti [11] using observation, questionnaire and interview as the data collecting technies. The study shows that there are four factors causing students' difficulties in learning and doing listening exercises which include limited time given to learn a listening skill, unavailability of adequate facilities contributed to students' difficulties in listening learning, limited vocabulary and paralinguistic features (accent, noise, rate of delivery, pronunciation, and intonation). Moreover, with questionnaire and interview, Hamouda [3] revealed some major problems in listening: accent, pronunciation, speed of speech, insufficient vocabulary, different accent, lack of concentration, anxiety, and bad quality of recording files.

With regards to the existence of listening comprehension difficulties foreign language learning and their factor, sas well as the urgency to investigate those diffulties and factors, this study is intended to find out the difficulties of listening skills in English as a foreign language learning faced by students and the factors of of those listening difficulties in the secondary school education context in Indonesia.

\section{METHOD}

In order to collect the data, the writer used questionnaire and interview. The questionnaire was adapted from Lotfi [9] which consists of 40 items and was used to gain numeric data of students' listening difficulties. These questions were assessed from 5 Likert Scale points ranging from formats: 1 (strongly disagree), 2 (disagree), 3 (neutral), 4 (agree), and 5 (strongly disagree). The interview which was adapted from Hamouda [3], consists of five questions to explore the factors of students' listening difficulties.

This study involved 100 eleventh grade students at a Senior High School in West Java who were asked o fill in the questionnaires. In addition, eight students took part in the interview. In choosing the participants, the writer used purposive sampling technique. Due to the pandemic situation in Indonesia, the questionnaires were transformed into Google Forms and shared online through WhatsApp class group. After the whole data had been collected, the questionnaire was inserted to IBM SPSS Statistic ver. 23 and analysed in a descriptive statistical choice to see the students' perception about their listening difficulties. Then, the data was moved into a table to be interpreted. The interview data was analyzed thematically through transcribing of the interview recording and coding of interview transcription with the themes relevant to the research questions. 


\section{RESULTS AND DISCUSSION}

This section presents the results of the study organised based on the data collecting methods; results gained from the questionnaires and those from the interviews.

\subsection{Questionnaire Result}

Data gained from the questionnares were classified by the frequency of every statement into percentage. The questionnaire data were calculated by scoring each item which weere then, input into the table. The following table show the results of the analysis of data from the questionnaires and were classified based on the six major categories of listening difficulties suggested by Lotfi [9].

\begin{tabular}{|c|c|c|c|c|}
\hline \multirow{2}{*}{ Classification } & \multirow{2}{*}{ Number } & \multicolumn{3}{|c|}{ Percentage } \\
\cline { 3 - 4 } & & SA + A & N & D + SD \\
\hline Process & $1,2,3,4,5,6,7,8,9,10,11,12$ & $52.34 \%$ & $27.75 \%$ & $19.92 \%$ \\
\hline Input & $13,14,15,16,17,18,19,20,21$ & $62.67 \%$ & $23.22 \%$ & $14.11 \%$ \\
\hline Listener & $22,23,24,25,26,27,28,29,30,31$ & $51.90 \%$ & $25.50 \%$ & $22.60 \%$ \\
\hline Task & $32,33,34$ & $51.67 \%$ & $62.33 \%$ & $20.67 \%$ \\
\hline Affect & $35,36,37,38$ & $62.50 \%$ & $23.25 \%$ & $14.25 \%$ \\
\hline Context & 39,40 & $91 \%$ & $7 \%$ & $2 \%$ \\
\hline
\end{tabular}

The table above shows teh percentages of six major problems of listening faced by students which include process, input, listener, task, problem, and context. It can be seen in the table that the highest percentage which show the common problems faced by students are those relate to the context $(91 \%)$. The second problems with second highes perentage are those relate to input (62.675). The third problems relate to affect $(62.50 \%)$. The next are problems dealing with the process $(52.34 \%)$.

\section{Process}

The fifth are problems relate to listener (51.90), and the problems of lowest percentage or the most uncommon listening problems faced by students are problema relate to the task $(52.67 \%)$.

The following tables present detailed percentages of students responses for every questionnaire item of the six major categories of listening difficulties.

\begin{tabular}{|c|c|c|c|c|c|c|c|}
\hline No. & Items & SA & A & N & D & SD & M \\
\hline 1 & $\begin{array}{c}\text { Before listening, it is difficult for me to } \\
\text { predict from the visuals what I will hear. }\end{array}$ & $13 \%$ & $34 \%$ & $30 \%$ & $18 \%$ & $5 \%$ & 3.32 \\
\hline 2 & $\begin{array}{c}\text { It is difficult for me to relate what I hear } \\
\text { with something from an earlier part of the } \\
\text { listening text. }\end{array}$ & $10 \%$ & $43 \%$ & $28 \%$ & $15 \%$ & $4 \%$ & 3.40 \\
\hline 5 & $\begin{array}{c}\text { While listening, I have problems making } \\
\text { meaningful personal associations with the } \\
\text { new information. }\end{array}$ & $8 \%$ & $39 \%$ & $30 \%$ & $21 \%$ & $2 \%$ & 3.30 \\
\hline 5 & $\begin{array}{c}\text { During listening, I have difficulty checking } \\
\text { whether I correctly understand the meaning } \\
\text { of the whole chunks of the listening text. }\end{array}$ & $24 \%$ & $38 \%$ & $24 \%$ & $11 \%$ & $3 \%$ & 3.69 \\
\hline $\begin{array}{c}\text { I have difficulty with finding out what the } \\
\text { main purpose of the listening task I am } \\
\text { going to do is. }\end{array}$ & $10 \%$ & $37 \%$ & $27 \%$ & $22 \%$ & $4 \%$ & 3.27 \\
\hline 7 & $\begin{array}{c}\text { When I listen to texts in English, I } \\
\text { experience difficulty with listening for the } \\
\text { main idea of the text. }\end{array}$ & $16 \%$ & $32 \%$ & $32 \%$ & $17 \%$ & $3 \%$ & 3.41 \\
\hline $\begin{array}{c}\text { I find it challenging to focus on the text } \\
\text { when I have trouble understanding. }\end{array}$ & $21 \%$ & $41 \%$ & $18 \%$ & $19 \%$ & $1 \%$ & 3.62 \\
\hline $\begin{array}{c}\text { While listening, I find it difficult to guess the } \\
\text { meaning of unknown words by linking them } \\
\text { to known words. }\end{array}$ & $19 \%$ & $36 \%$ & $27 \%$ & $15 \%$ & $3 \%$ & 3.53 \\
\hline
\end{tabular}




\begin{tabular}{|c|c|c|c|c|c|c|c|}
\hline 9 & $\begin{array}{c}\text { I find it difficult to make a mental summary } \\
\text { of information gained through listening. }\end{array}$ & $15 \%$ & $38 \%$ & $22 \%$ & $20 \%$ & $5 \%$ & 3.38 \\
\hline 10 & $\begin{array}{c}\text { While listening, I have difficulty to check } \\
\text { my understanding of the text based on what I } \\
\text { already know about the topic. }\end{array}$ & $9 \%$ & $39 \%$ & $32 \%$ & $18 \%$ & $2 \%$ & 3.35 \\
\hline 11 & $\begin{array}{c}\text { I find it difficult to use the context to guess } \\
\text { those parts of a listening text that I cannot } \\
\text { hear clearly. }\end{array}$ & $18 \%$ & $40 \%$ & $29 \%$ & $11 \%$ & $2 \%$ & 3.61 \\
\hline 12 & $\begin{array}{c}\text { After listening, I find it difficult to evaluate } \\
\text { the overall accuracy of my comprehension. }\end{array}$ & $8 \%$ & $40 \%$ & $34 \%$ & $18 \%$ & $0 \%$ & 3.38 \\
\hline
\end{tabular}

Items number $1,2,3,6,8,9$ and 11 reflect the using of cognitive strategies of between-parts inferencing, prediction, personal elaboration, linguistic inferencing, summarization, contextualization and listening for the main idea. Item number $4,5,7,10,12$ reflect the using of Input

\begin{tabular}{|c|c|c|c|c|c|c|c|}
\hline No. & Items & SA & A & N & D & SD & M \\
\hline 13 & $\begin{array}{c}\text { I find it difficult to understand listening texts } \\
\text { in which there are too many unfamiliar } \\
\text { words. }\end{array}$ & $20 \%$ & $32 \%$ & $29 \%$ & $17 \%$ & $2 \%$ & 3.35 \\
\hline 14 & $\begin{array}{c}\text { I find it difficult to understand the meaning } \\
\text { of words which are not pronounced clearly. }\end{array}$ & $29 \%$ & $44 \%$ & $19 \%$ & $5 \%$ & $3 \%$ & 3.91 \\
\hline 15 & $\begin{array}{c}\text { I find it difficult to understand listening texts } \\
\text { which have difficult grammatical structures. }\end{array}$ & $30 \%$ & $37 \%$ & $22 \%$ & $8 \%$ & $3 \%$ & 3.83 \\
\hline 16 & $\begin{array}{c}\text { I find it difficult to understand well when } \\
\text { speakers speak too fast. }\end{array}$ & $45 \%$ & $29 \%$ & $18 \%$ & $8 \%$ & $0 \%$ & 4.11 \\
\hline 17 & $\begin{array}{c}\text { Unfamiliar stress and intonation patterns of } \\
\text { English interfere with my listening } \\
\text { comprehension. }\end{array}$ & $18 \%$ & $29 \%$ & $28 \%$ & $21 \%$ & $4 \%$ & 3.36 \\
\hline 19 & $\begin{array}{c}\text { I find it difficult to understand the listening } \\
\text { text when speakers speak with varied } \\
\text { accents. }\end{array}$ & $23 \%$ & $36 \%$ & $26 \%$ & $14 \%$ & $1 \%$ & 3.66 \\
\hline 20 & $\begin{array}{c}\text { I find it difficult to interpret the meaning of a } \\
\text { lext when listening text. }\end{array}$ & $28 \%$ & $32 \%$ & $25 \%$ & $13 \%$ & $2 \%$ & 3.71 \\
\hline 21 & $\begin{array}{c}\text { I have difficulty understanding speakers with } \\
\text { unfamiliar accents. }\end{array}$ & $29 \%$ & $36 \%$ & $21 \%$ & $11 \%$ & $3 \%$ & 3.77 \\
\hline
\end{tabular}

Input problem gets the percentage at $62.67 \%$. Input here means the target language that reaches the learners' auditory system in listening. It relates to input characteristics as vocabulary (item 13), speech clarity metacognitive strategies. Strategies of planning (item 5 and 7), monitoring (item 4 and 10), and evaluation (item 12). Overall, problems dealing with process has the percentage of 52.34 .

\section{Listener}

\begin{tabular}{|c|c|c|c|c|c|c|c|}
\hline No. & Items & SA & A & N & D & SD & M \\
\hline 22 & $\begin{array}{c}\text { When thinking about meaning of unfamiliar } \\
\text { words, I neglect the next part of the listening } \\
\text { text. }\end{array}$ & $13 \%$ & $40 \%$ & $26 \%$ & $17 \%$ & $4 \%$ & 3.41 \\
\hline 23 & $\begin{array}{c}\text { I am slow to recall the meaning of words } \\
\text { that sound familiar. }\end{array}$ & $15 \%$ & $23 \%$ & $34 \%$ & $21 \%$ & $7 \%$ & 3.18 \\
\hline
\end{tabular}




\begin{tabular}{|c|c|c|c|c|c|c|c|}
\hline 24 & $\begin{array}{c}\text { I find it difficult to quickly remember words } \\
\text { or phrases I have just heard. }\end{array}$ & $21 \%$ & $31 \%$ & $24 \%$ & $23 \%$ & $1 \%$ & 3.48 \\
\hline 25 & $\begin{array}{c}\text { During listening, although some words } \\
\text { sound familiar, it is difficult for me to recall } \\
\text { their meaning immediately. }\end{array}$ & $14 \%$ & $38 \%$ & $21 \%$ & $21 \%$ & $6 \%$ & 3.33 \\
\hline 26 & $\begin{array}{c}\text { When I hear the new words. I forget the } \\
\text { content which was mentioned before. }\end{array}$ & $9 \%$ & $39 \%$ & $21 \%$ & $28 \%$ & $3 \%$ & 3.32 \\
\hline 27 & $\begin{array}{c}\text { I lose the flow of speech because I } \\
\text { concentrate very hard on understanding } \\
\text { every words or phrase I hear. }\end{array}$ & $19 \%$ & $41 \%$ & $26 \%$ & $12 \%$ & $2 \%$ & 3.63 \\
\hline 28 & $\begin{array}{c}\text { I find it difficult to remember the meaning of } \\
\text { a long listening text. }\end{array}$ & $22 \%$ & $49 \%$ & $20 \%$ & $9 \%$ & $0 \%$ & 3.84 \\
\hline 29 & $\begin{array}{c}\text { I find it difficult to really concentrate on } \\
\text { listening. }\end{array}$ & $17 \%$ & $33 \%$ & $26 \%$ & $19 \%$ & $5 \%$ & 3.38 \\
\hline 30 & $\begin{array}{c}\text { I have difficulty comprehending the listening } \\
\text { text because I don't know which strategy to } \\
\text { use while listening. }\end{array}$ & $20 \%$ & $36 \%$ & $31 \%$ & $12 \%$ & $1 \%$ & 3.62 \\
\hline 31 & $\begin{array}{c}\text { I have difficulty understanding a listening } \\
\text { text because I cannot understand every } \\
\text { single word I hear. }\end{array}$ & $16 \%$ & $23 \%$ & $26 \%$ & $26 \%$ & $9 \%$ & 3.11 \\
\hline
\end{tabular}

The problems relate to listener consists of 10 items which reflect learners' belief about characteristics in the literature of learners. The characteristics include attention (items 22, 27 and 29), attitude (items 30 and 31), and memory (items 23, 24, 25, 26 and 28).

Task

\begin{tabular}{|c|c|c|c|c|c|c|c|}
\hline No. & Items & SA & A & N & D & SD & M \\
\hline 32 & $\begin{array}{c}\text { I find it difficult to do listening tasks, such } \\
\text { as filling a grid, for which I need to draw on } \\
\text { specific information from the text. }\end{array}$ & $19 \%$ & $37 \%$ & $31 \%$ & $12 \%$ & $1 \%$ & 3.61 \\
\hline 33 & $\begin{array}{c}\text { I find it difficult to do listening tasks for } \\
\text { which I need to combine information to } \\
\text { make generalization while listening to the } \\
\text { text. }\end{array}$ & $16 \%$ & $48 \%$ & $21 \%$ & $15 \%$ & $0 \%$ & 3.65 \\
\hline 34 & $\begin{array}{c}\text { I find it difficult to answer WH-Questions in } \\
\text { a listening task. }\end{array}$ & $13 \%$ & $22 \%$ & $31 \%$ & $26 \%$ & $8 \%$ & 3.06 \\
\hline
\end{tabular}

Task problems get the lowest percentage od $51.67 \%$. It reflects learners' beliefs about problems with characteristics of listening task. Problems associated with task type reflected on item 33, type of responses when answering reflected on item 34 , and local question reflected on item 32 .

\section{Affect}

\begin{tabular}{|c|c|c|c|c|c|c|c|}
\hline No. & Items & SA & A & N & D & SD & M \\
\hline 35 & $\begin{array}{c}\text { I stop listening when I have problems in } \\
\text { understanding a listening text. }\end{array}$ & $17 \%$ & $39 \%$ & $26 \%$ & $13 \%$ & $5 \%$ & 3.50 \\
\hline 36 & $\begin{array}{c}\text { If I don't arrive at a total comprehension of } \\
\text { an oral text. I feel disappointed. }\end{array}$ & $35 \%$ & $35 \%$ & $19 \%$ & $6 \%$ & $5 \%$ & 3.89 \\
\hline 37 & $\begin{array}{c}\text { I find it difficult to reduce my anxiety before } \\
\text { doing the listening task. }\end{array}$ & $20 \%$ & $38 \%$ & $26 \%$ & $12 \%$ & $4 \%$ & 3.58 \\
\hline $\begin{array}{c}\text { Before doing listening comprehension task, I } \\
\text { fear that I cannot understand what I will } \\
\text { hear. }\end{array}$ & $28 \%$ & $38 \%$ & $22 \%$ & $7 \%$ & $5 \%$ & 3.77 \\
\hline
\end{tabular}


Problems related to affect gets the percentage at $62.50 \%$. It consists of four items which reflect learners' beliefs about problem of affective dimension of listening.
Problems on comprehension failure are reflected on items 35 and 36. Level of anxiety in listening are reflected on items 37 and 38 .

\section{Context}

\begin{tabular}{|c|c|c|c|c|c|c|c|}
\hline No. & Items & SA & A & N & D & SD & M \\
\hline 39 & $\begin{array}{c}\text { Unclear sounds resulting from a poor-quality } \\
\text { CD-player interfere with my listening } \\
\text { comprehension. }\end{array}$ & $53 \%$ & $39 \%$ & $6 \%$ & $2 \%$ & $0 \%$ & 4.43 \\
\hline 40 & $\begin{array}{c}\text { Unclear sounds resulting from a poor } \\
\text { acoustic conditions of the classroom } \\
\text { interfere with my listening comprehension. }\end{array}$ & $54 \%$ & $36 \%$ & $8 \%$ & $1 \%$ & $1 \%$ & 4.41 \\
\hline
\end{tabular}

Problems dealing with context has the highest percentage of $91 \%$. The context relates to learners' beliefs about learning context affecting listening comprehension. The items reflect problems caused by contextual features as tool to play recordings (item 39) and bad condition of the classroom (item 40).

\subsection{Interview Result}

The first core question was asked to know the problems faced by students during learning listening comprehension. The results show that all of the interviewees gave various responses.

\subsubsection{Difficulties of Listening}

\section{1) Unfamiliar words}

Five out of eight interviewees stated that one of the most common difficulties is unfamiliar words. SN claimed that when listening to the audio, he found that there are unfamiliar words which he doesn't understand,

- "There are words which I haven't heard so I don't understand. New words, I just heard."-SN Another student (EZ) said that listening materials such as songs or movies mostly consist of some new words which he never heard before,

- "There must be new words I haven't heard before from movies or songs." -EZ

In the listening materials, students sometimes face unfamiliar words which makes them confused. AF stated,

- "Unfamiliar words sometimes confuse me about the meaning, but if it is familiar to me it will be easy." -AF

NY and BT's responses strengthened the previous statements from students that unfamiliar words become a problem in learning listening material.

- " "Many words I don’t understand." -NY

- " "...from the words I haven't heard before."-BT

2) Rate of speech

Another difficulty is that most students feel difficult on the speaker's speech rate. Which is conveyed by AR:
- "Sometimes it is too fast. It jumps to the next section when I'm thinking about the previous one." - AR

AF also stated the same problem. He said that sometimes if the speaker talks too fast, he would get confused.

3) Accent

"If they speak to fast makes me confused." -AF

Accent also matters to the students listening comprehension. Most of them feel difficult if they listen to the speaker who speaks with unfamiliar accent. As one of the interviewees put it:

"I think because I haven't known the accent before. It's unfamiliar." -BT

In addition, other responses to this question stated that British is quite unfamiliar accent:

- "The speaker talks with British accent, so it's quite hard to understand." -NY

4) Unclear pronunciation

Another difficulty found by the students is unclear pronunciation of the speaker. Sometimes, teachers don't use an audio of native speaker, but they created the listening materials by themselves. It actually becomes a difficulty for students because teachers do not pronounce the materials clearly.

This difficulty is evidenced by responses of the interviewee:

"Sometimes teacher is unclear in pronouncing the words." -AF

SN also stated that:

- "Yes the unclear pronunciation matters to my listening comprehension." - SN

5) Recording quality

Besides those mentioned difficulties, there is another problem from the external of the students. It is recording quality. Most students believe if the quality of the recording material also matters to their listening comprehension. They feel difficult if the quality is bad. It is proven by one of the interviewee's response:

"It becomes harder because the sound is too low, so I can't hear it clearly." -IZ 
Another students stated that the quality of the recording is quite bad. The sound is not clear enough for students to hear.

"When listen to the song in listening learning, the speaker is bad. The lyrics also unclear to hear." - AF

6) Inadequate facility

In addition, school have inadequate facility to do listening activity. It is evidenced by the interviewee's response which said that do to the listening activity, teachers usually borrow students' mobile phone to get the material and connect it to the speaker,

"The teacher often borrows the student's phone with the high sound and plug it into the recording machine." - RS

Overall, the results of the interview data analysis show that students faced some difficulties in learning listening which include unfamiliar words, rate of speech, unfamiliar accent, unclear pronunciation, quality of recording, and inadequate facility.

\subsubsection{Factors of Listening Difficulties}

The second core question was asked to know the factors of their difficulties in listening. There are some factors which affect the difficulties in listening. Some students stated various responses toward this question.

1) Background knowledge

The main factor of the difficulties is background knowledge. Someone can understand something if they have previous knowledge about the things. It affects students who do not have any background knowledge to face the difficulties. It is shown in the following extract of the interview,

"In my opinion, students don't know much about previous English materials and it matters to their comprehension. For example, when taking the listening test, my friend was confused because he doesn't understand." -AF

It is emphasised by another interviewee who stated the same thing,

"...because they don't have background knowledge about English." -NY

2) Lack of practices

In addition, most interviewees mentioned that they felt difficult in listening because they are lazy to do practices. They said that they only do the listening activities in school without practice it at home or other places. It is proven by some responses of interviewees,

"I don't practice more." -IZ

"My English isn't practice that much." -SN

Some of them also stated that their teachers seldom to give more practices in the class. In the other language, the teachers not really focus in the listening skill. As one interviewee put it:

$$
\text { “...teacher rarely give us practice.”-EZ }
$$

3) Environment noise

The last factor which mentioned by some interviewee is environment noise. School has many students in it and the buildings are attached. It can be a factor to the students' listening difficulties. One informant reported that,

"...the classroom is very near from the school yard, so the noises from outside bothers us in the classroom." -BT

It can be seen from the answers above that the factors of students listening difficulties are background knowledge, lack of practice and environment noise.

As stated previously, the first major problem is related to the context. It is because the students feel difficult when they listen to the materials due to bad situation caused by classroom noise or bad quality of recording player. It is in line with Hamouda's [3] statement that noise is another environmental barrier to students in comprehending their listening. Moreover, the finding that a big number of students strongly agree if unclear sounds resulting from a poor-quality of CDplayer interfere their listening comprehension is relevant with the study conducted by Gilakjani AP, Sabouri [2] which reveal that quality of recorded materials is one of the major problems faced by students in listening comprehension.

The problems faced by students are not only related to the context, but input matters also to them. Students feel difficult to understand listening texts in which there are too many unfamiliar words. In this regards, Goh [12] said that vocabulary which is unfamiliar might be an obstacle for students in understanding the listening text. Moreover, the use of unfamiliar words in the text which listeners don't know, can make listeners stop and think to understand the meaning for a while [2]. In relation to the listening difficulties dealing with the pronunciation, unclear speech by teachers also posed difficulty for the students [13]. Students also feel difficult to understand listening texts due to difficult grammatical structures. Difficult grammatical structures must be unlocked by doing more practice since it may be the main source of listening comprehension problem for students [14]. Another listening difficulty is when speakers speak too fast. It is in line with Vandergrift [15] who revealed that an external factor which can fail students to comprehend the listening material is speech rate.

Among other difficulties, those related to the process in which students need to relate what they hear with something from an earlier part of the listening text became an aspect of particular concern. Topic unfamiliarity is one of students' difficulties in listening [13]. Topic They have problems making meaningful association with the new information while listening. Effective listeners use their background knowledge and relate those to the new information in the spoken content, so it will help them to comprehend the text as they process 
it [14]. To do listening activities, students should have some prior knowledge to comprehend new information. If the process is successful, the information will be accurately reconstructed. But if the process is unsuccessful, the information is inaccurately reconstructed [13]. In a situation where most people don't understand English, it is required to simulate to do more practices in listening. [16] claimed on his research that lack of practice is considered by teachers and students as the most important factor in listening difficulties. Those responses from both questionnaire and interview should be a consideration for teachers in teaching listening skill at school.

\section{CONCLUSION}

The difficulties in listening skills faced by students include unfamiliar words, rate of speech, unfamiliar accent, unclear pronunciation, recording quality, and inadequate facility. As for the factors of those difficulties, it involed the students' background knowledge, lack of practices and environment noise.

\section{REFERENCES}

[1] N. Husain, "What is Language? English Language Language as Skill," Language and Language Skills, no. March, pp. 1-11, 2015.

[2] A. P. Gilakjani and N. B. Sabouri, "Learners' Listening Comprehension Difficulties in English Language Learning: A Literature Review," English Language Teaching, vol. 9, no. 6, p. 123, 2016, doi: 10.5539/elt.v9n6p123.

[3] A. Hamouda, "An Investigation of Listening Comprehension Problems Encountered by Saudi Students in the EL Listening Classroom," vol. 2, no. 2, pp. 113-155, 2013.

[4] M. Rost, Teaching and Researching Listening Skills. 2011.

[5] L. Gu, "A Review of the Theories and Principles of Teaching Listening and Their Guidance in Senior High English Lessons in Mainland China," Studies in English Language Teaching, vol. 6, no. 1, p. 35, 2018, doi: 10.22158/selt.v6n1p35.

[6] M. W. G. Teri S. Kwal Gamble, Interpersonal Communication. 2013.

[7] Ö. G. Ulum, "Listening: The Ignored Skill in EFL Context.," Online Submission, vol. 2, no. 5, pp. 72-76, 2015.

[8] F. Yagang, "Listening: Problems and Solutions," Journal of Chemical Information and Modeling, vol. 53, no. 9, pp. 1689-1699, 2019, doi: 10.1017/CBO9781107415324.004.
[9] G. Lotfi, “A questionnaire of beliefs on English language listening comprehension problems: Development and validation," World Applied Sciences Journal, vol. 16, no. 4, pp. 508-515, 2012.

[10] R. Maulida, "AN ANALYSIS OF STUDENTS' DIFFICULTIES IN LEARNING LISTENING (A Study at SMAN 11 Banda Aceh) THESIS," 2018.

[11] Darti, "Analyzing Students ' Difficulties Toward Listening Comprehension of English Education Department of Tarbiyah and Teaching Faculty At Uin Alauddin State Islamic University of Makassar," 2017.

[12] C. C. Goh, "A cognitive perspective on language learners' listening comprehension problems," System, vol. 28, pp. 55-75, 2000, doi: doi.org/10.1016/S0346-251X(99)00060-3.

[13] Z. Donglan, "'Your english is too cheem!': Singaporean student listening difficulties and tackling strategies," Asian Englishes, vol. 7, no. 1, pp. 74-91, 2004, doi: 10.1080/13488678.2004.10801132.

[14] A. S. Hasan, "Learners' perceptions of listening comprehension problems," Language, Culture and Curriculum, vol. 13, no. 2, pp. 137-153, 2000, doi: 10.1080/07908310008666595.

[15] L. Vandergrift, C. C. M. Goh, C. J. Mareschal, and M. H. Tafaghodtari, "The metacognitive awareness listening questionnaire: Development and validation," Language Learning, vol. 56, no. 3, pp. 431-462, 2006, doi: 10.1111/j.14679922.2006.00373.x.

[16] J. P. Boyle, "Factors affecting listening comprehension," ELT Journal, vol. 38, no. 1, pp. 34-38, 1984, doi: 10.1093/elt/38.1.34. 